\title{
THE NATURE OF THE PROTECTIVE EFFECT OF ANTISERA AGAINST ESCHERICHIA COLI DIARRHOEA IN PIGLETS
}

\author{
H. Williams Smith \\ Houghton Poultry Research Station, Houghton, Huntingdon
}

IN studies on experimental Escherichia coli diarrhoea in gnotobiotic piglets, Kohler and Bohl (1966), Kohler (1967) and Miniats, Mitchell and Barnum (1970) observed that the protective effect of antiserum was not associated with a marked reduction in the concentration of the organisms of the infecting strain in the contents of the small intestine, suggesting that this effect was antienterotoxic rather than antibacterial in nature. In somewhat similar studies on conventionally reared weaned pigs Smith and Linggood (1971b), however, found much lower concentrations of the infecting organisms in the small intestine of antiserum-protected animals than in the unprotected controls, suggesting that the antibacterial effect of antiserum was important in preventing clinical infection. In view of these apparently conflicting observations, fresh experiments were designed with the purpose of elucidating the parts played by antibacterial and anti-enterotoxic antibodies in controlling $E$. coli diarrhoea in the piglet. Orally administered antiserum was mainly studied because under natural conditions piglets receive practically all their antibodies from colostrum.

\section{MATERIALS AND METHODS}

Piglets. These belonged to the herd described previously by Smith and Linggood (1971a).

Inoculation method. The piglets in each litter were removed from their mother immediately after they were born, and before they had consumed colostrum, and placed in clean heated boxes. They were given, by stomach tube, $20 \mathrm{ml}$ of antiserum mixed with $20 \mathrm{ml}$ of canned evaporated milk suitably diluted with water. Two hours later they were given, by mouth, $10^{7}$ viable organisms of a nalidixic-acid resistant mutant of a porcine enteropathogenic strain of Escherichia coli $(\mathrm{O} 141: \mathrm{K} 85 \mathrm{ab}, 88 \mathrm{ab})$ and $10^{9}$ viable organisms of a streptomycin-resistant mutant of a non-pathogenic strain $(\mathrm{O} 9: \mathrm{K} 36: \mathrm{H} 19)$ as well as approximately $3 \times 10^{9}$ viable organisms of a culture of lactobacilli isolated originally from the faeces of a healthy pig. When it was desired to study mixed infections of enteropathogenic strains, $10^{7}$ viable organisms of an ampicillin-resistant mutant of an 08:K87,88ab enteropathogen were included in the inoculum. After infection, the piglets were given the diluted evaporated milk ad libitum and observed frequently for evidence of diarrhoea.

Bacteriological examination of piglets. At appropriate times the piglets were killed and the concentration of viable $E$. coli and lactobacilli in the different parts of their alimentary tract estimated by the methods of Smith and Linggood (1971a). Rogosa's medium (Rogosa, Mitchell and Wiseman, 1951) was used for enumerating the lactobacilli and MacConkey's medium containing $20 \mu \mathrm{g}$ per $\mathrm{ml}$ of sodium nalidixate, streptomycin or ampicillin for enumerating the $E$. coli mutants.

Antisera. These were prepared in pigs by the methods of Smith and Linggood (1971b).

Received 6 Dec. 1971; accepted 3 Feb. 1972.

J. MED. MICROBIOL. - VOL. 5 (1972) 


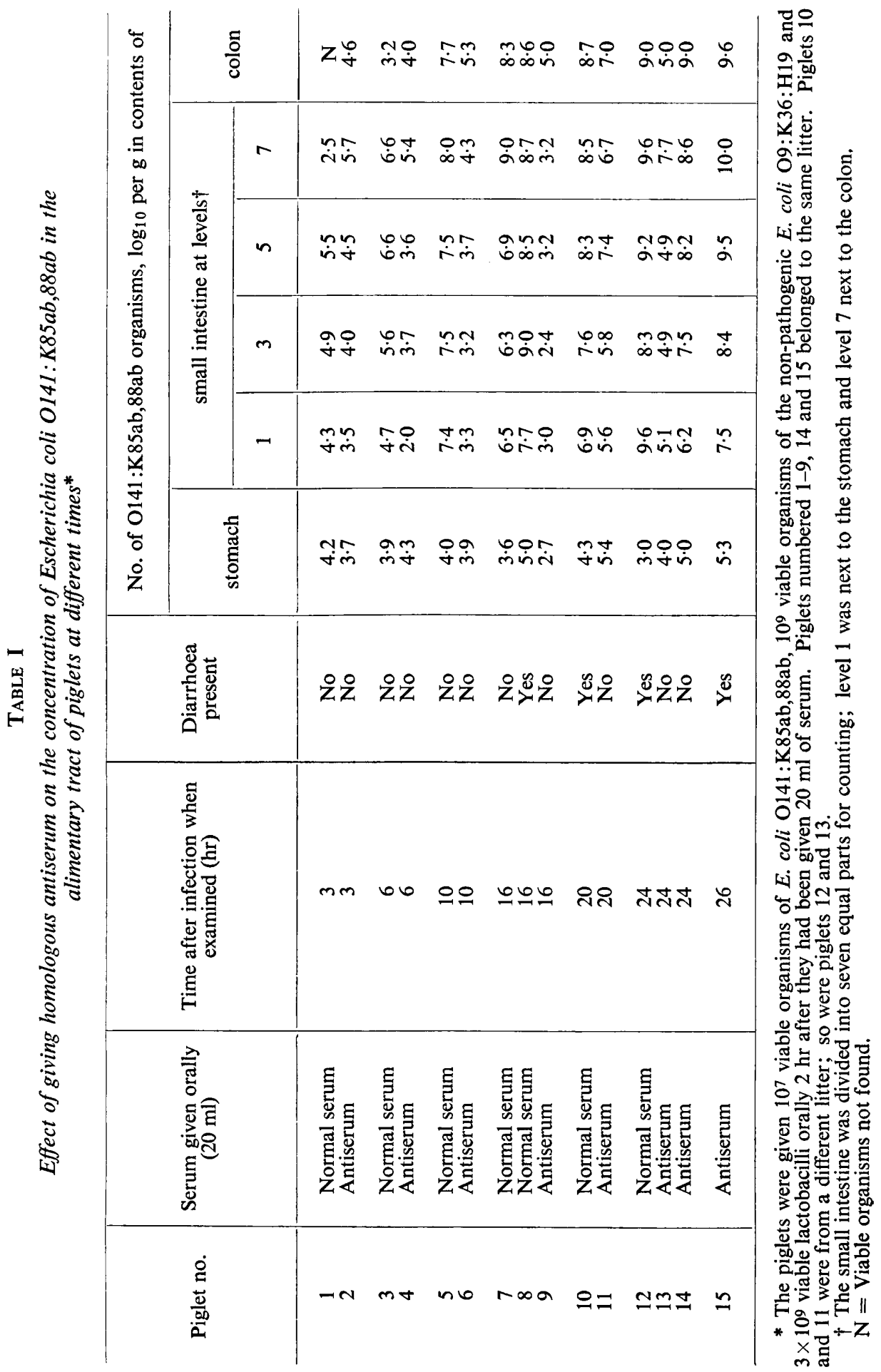




\section{RESULTS}

Effect of Escherichia coli O141:K85ab,88ab antiserum given orally on the concentration of organisms in the alimentary tract of piglets at different times after infection

The results of estimating the concentrations of $\mathrm{O} 141: \mathrm{K} 85 \mathrm{ab}, 88 \mathrm{ab}$ organisms in the alimentary tract of pairs of piglets, one given normal serum and the other antiserum against live $\mathrm{O} 141: \mathrm{K} 85,88 \mathrm{ab}$ organisms, at different times after infection with $10^{7}$ of these organisms, $10^{9}$ organisms of the non-pathogenic E. coli O9: K36: $\mathrm{H} 19$ and $3 \times 10^{9}$ lactobacilli are summarised in table I. The

TABLE II

Effect of antisera prepared against differently treated $0141: K 85 a b, 88 a b$ organisms and administered orally

\begin{tabular}{|c|c|c|c|c|c|c|c|}
\hline \multirow{3}{*}{$\begin{array}{l}\text { Litter } \\
\text { no. }\end{array}$} & \multicolumn{7}{|c|}{$\begin{array}{l}\text { Time between infection and development of } \\
\text { diarrhoea (hr) in piglets given }\end{array}$} \\
\hline & \multirow{2}{*}{\multicolumn{2}{|c|}{ normal serum }} & \multicolumn{5}{|c|}{$\begin{array}{c}\text { antiserum prepared against } \mathrm{O} 141: \mathrm{K} 85 \mathrm{ab}, 88 \mathrm{ab} \\
\text { organisms that were }\end{array}$} \\
\hline & & & $\begin{array}{l}\text { methanol- } \\
\text { killed }\end{array}$ & \multicolumn{2}{|c|}{ heat-killed } & \multicolumn{2}{|c|}{ live } \\
\hline 1 & $11 \frac{1}{2}$, & 16 & $18 \frac{1}{2}, \quad 21 \frac{1}{2}$ & $14 \frac{1}{2}$, & $18 \frac{1}{2}$ & $21 \frac{1}{2}$ & 30 \\
\hline 2 & 12 & $15 \frac{1}{2}$ & $32 \frac{1}{2},>48$ & 43 & 46 & 43 & $>48$ \\
\hline
\end{tabular}

Two piglets in each litter were given each kind of serum.

For other details see table I.

concentration of $\mathrm{O} 141: \mathrm{K} 85 \mathrm{ab}, 88 \mathrm{ab}$ organism in the small intestine of the piglets given normal serum increased progressively with time. They were sufficiently high in one of those examined at $16 \mathrm{hr}$ and in both animals examined subsequently to cause severe diarrhoea. By contrast, the numbers of these organisms in the piglets given antiserum and examined 3-16 hr after infection remained very low. Only moderately high concentrations were found in those killed at 20 and $24 \mathrm{hr}$. High concentrations were found in the one animal killed at $26 \mathrm{hr}$; this piglet was the only one in the group to develop diarrhoea, the diarrhoea having commenced $1 \mathrm{hr}$ previously. The difference between the numbers of $0141: \mathrm{K} 85 \mathrm{ab}, 88 \mathrm{ab}$ organisms in the stomach contents of all the piglets, irrespective of whether or not they had been given antiserum, was not great; they were always greatly outnumbered by organisms of the O9: K36: H19 strain and by the lactobacilli. In the small intestine of all the piglets in which they were not actively proliferating, the $\mathrm{O} 141: \mathrm{K} 85 \mathrm{ab}, 88 \mathrm{ab}$ organisms were outnumbered by the $09: \mathrm{K} 36: \mathrm{H} 19$ organisms and lactobacilli. For example the concentrations of $\mathrm{O} 9: \mathrm{K} 36: \mathrm{H} 19$ organisms in the contents of the stomach, in positions $1,3,5$ and 7 of the small intestine and in the colon of piglet no. 4 in 
table I was: $\log _{10}$ per $\mathrm{g}, 6 \cdot 0,6 \cdot 0,6 \cdot 5,7 \cdot 0,8 \cdot 6$ and $8 \cdot 0$ respectively. The corresponding figures for lactobacilli were $7 \cdot 5,6 \cdot 6,7 \cdot 5,7 \cdot 6,8 \cdot 0$ and $8 \cdot 4$. There was, however, considerable variation from piglet to piglet.

The results of giving two piglets from each of two litters normal serum or antisera prepared against live, heat-killed or methanol-killed $0141: \mathrm{K} 85 \mathrm{ab}$,88ab organisms and then assessing the interval between infection with these organisms, the O9: K36:H19 organisms and the lactobacilli and the onset of diarrhoea is summarised in table II. With one exception, the interval was longer in

TABLE III

Effect of antisera prepared against porcine enteropathogenic strains of Escherichia coli of differing antigenic structure and administered orally on the diarrhoea-producing activity of E. coli O141:K85ab,88ab

\begin{tabular}{|c|c|c|c|c|c|c|c|}
\hline \multirow{3}{*}{$\begin{array}{l}\text { Litter } \\
\text { no. }\end{array}$} & \multicolumn{7}{|c|}{$\begin{array}{c}\text { Time between infection with strain O141:K85ab,88ab and the onset of diarrhoea (hr) } \\
\text { in piglet given }\end{array}$} \\
\hline & \multirow{2}{*}{$\begin{array}{l}\text { normal } \\
\text { serum }\end{array}$} & \multicolumn{6}{|c|}{ antiserum against strains of the following antigenic structure } \\
\hline & & O138:K81 & O139:K82 & O9:K9 & $\mathrm{O} 8: \mathrm{K} 87^{*}$ & O8:K87,88ab & O141:K85ab,88ab \\
\hline 1 & 8 & 10 & 12 & 12 & $\ldots$ & $\ldots$ & $>25$ \\
\hline 2 & 11 & $\ldots$ & $\ldots$ & $\ldots$ & 14 & 28 & 34 \\
\hline 3 & 15 & $\ldots$ & $\ldots$ & $\ldots$ & 15,18 & $22-28 \dagger, 22-28 \dagger$ & $22-28 \dagger$ \\
\hline
\end{tabular}

The number of observations recorded corresponds to the number of piglets used.

* This was the $\mathrm{O} 8: \mathrm{K} 87,88 \mathrm{ab}$ strain that had lost its plasmid coding for $\mathrm{K} 88$ antigen production. $\dagger=$ Diarrhoea began at an undetermined time between 22 and $28 \mathrm{hr}$.

For other details see table I.

the piglets given antisera than in those given normal serum. This was particularly the case in litter no. 2 , there being little difference in this respect between the three groups given the different kinds of antiserum. The piglets that developed diarrhoea had high concentrations of $\mathrm{O} 141: \mathrm{K} 85,88 \mathrm{ab}$ organisms in the contents of their small intestine. Either low or only moderately high concentrations were found in the small intestines of the two piglets that did not have diarrhoea when the experiment was terminated at $48 \mathrm{hr}$.

Effect of antisera prepared against enteropathogenic strains of $E$. coli of differing antigenic structure on the diarrhoea-producing activity of $E$. coli O141: K85ab,88ab

The results of giving orally to piglets antisera prepared against live enteropathogenic strains of $E$. coli of differing antigenic structure and then infecting them with $\mathrm{O} 141: \mathrm{K} 85 \mathrm{ab}, 88 \mathrm{ab}, \mathrm{O} 9: \mathrm{K} 36: \mathrm{H} 19$ organisms and lactobacilli are summarised in table III. There was only a small difference in the time of onset 
ANTISERA TO E. COLI IN DIARRHOEA

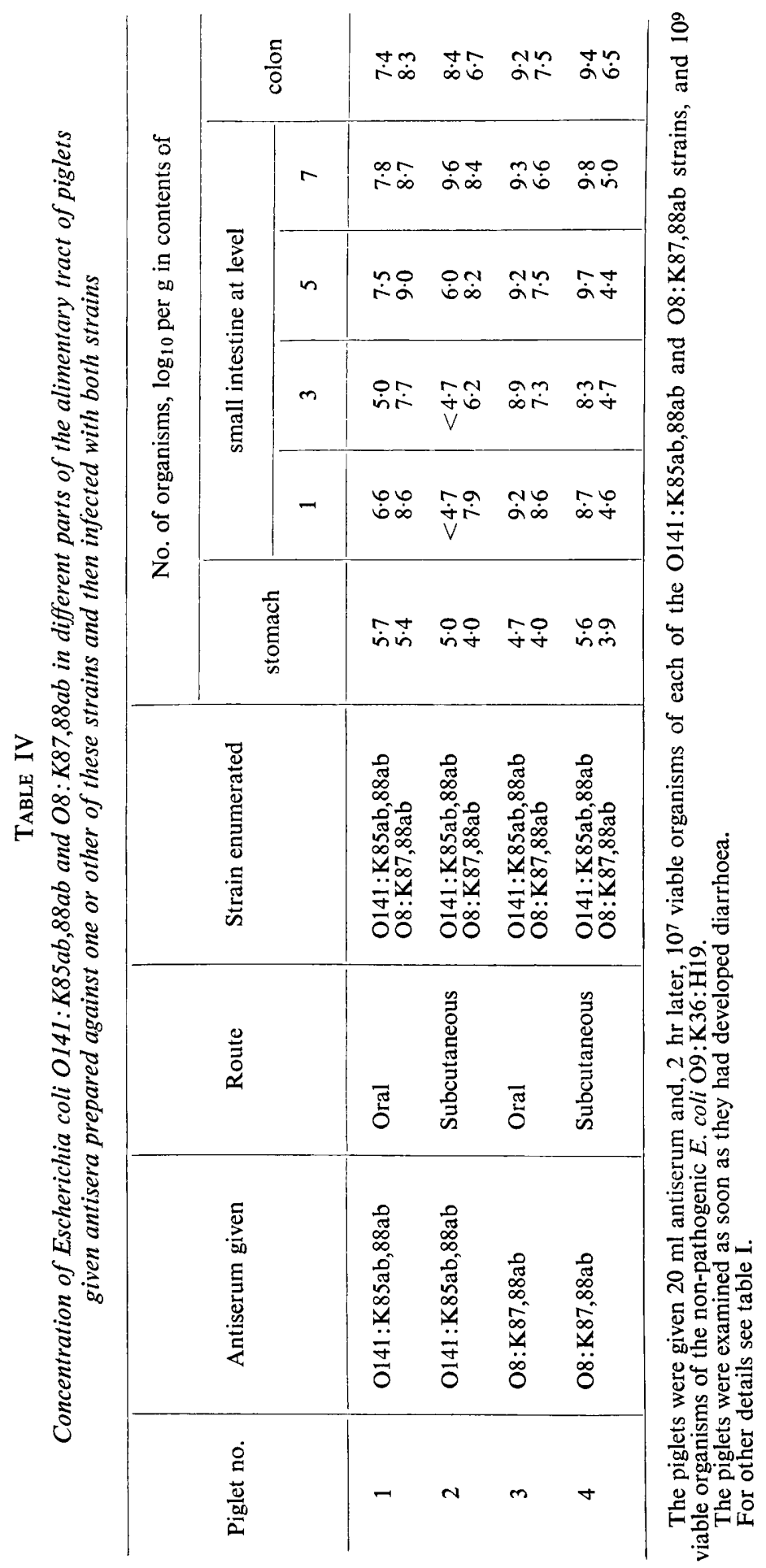


of diarrhoea between the piglets given normal serum and those given antisera against strains that did not possess any of the recognised $\mathrm{O}$ or $\mathrm{K}$ antigens of $E$. coli $\mathrm{O} 141$ : K85ab,88ab. The interval was much shorter than that observed in the piglets given $\mathrm{O} 141: \mathrm{K} 85 \mathrm{ab}, 88 \mathrm{ab}$ antiserum. The strain used to produce the $08: \mathrm{K} 87$ antiserum was a form of the $08: \mathrm{K} 87,88 \mathrm{ab}$ strain that had lost its plasmid coding for K88 antigen production. By contrast, the antiserum prepared against the original $\mathrm{K}_{88^{+}}$strain had an appreciable delaying effect on the onset of diarrhoea, approaching that produced by the $0141: \mathrm{K} 85 \mathrm{ab}, 88 \mathrm{ab}$ antiserum itself; $\mathrm{K} 88$ is the only recognised antigen shared by the $\mathrm{O} 8: \mathrm{K} 87,88 \mathrm{ab}$

\section{TABLE V}

Effect of antiserum prepared against Escherichia coli $\mathrm{K}_{2} \mathrm{~F}^{-} \mathrm{Ent}^{+}$on the diarrhoea-producing activity of E. coli O141: K85ab,88ab

\begin{tabular}{|c|c|c|c|}
\hline \multirow{2}{*}{$\begin{array}{c}\text { Litter } \\
\text { no. }\end{array}$} & \multicolumn{3}{|c|}{$\begin{array}{l}\text { Time between infection with strain } 0141: \mathrm{K} 85 \mathrm{ab}, 88 \mathrm{ab} \text { and the } \\
\text { onset of diarrhoea (hr) in piglet* given antiserum against the } \\
\text { following strains of } E \text {. coli }\end{array}$} \\
\hline & $\mathrm{K} 12 \mathrm{~F}^{-}$ & $\mathrm{K} 12 \mathrm{~F}^{-} \mathrm{Ent}^{+}$ & $\mathrm{O} 141: \mathrm{K} 85 \mathrm{ab}, 88 \mathrm{ab}$ \\
\hline 4 & $12-16,12-16,12-16,12-16$ & $12-16,12-16,20$ & $>21,>21$ \\
\hline 5 & 11 & 13 & 34 \\
\hline
\end{tabular}

The Ent plasmid had been transmitted to the $\mathrm{K} 12 \mathrm{~F}^{-}$strain from the $\mathrm{O} 8: \mathrm{K} 87,88 \mathrm{ab}$ strain referred to in tables III and IV.

* The number of observations recorded corresponds to the number of piglets used.

For other details see tables I and III.

and $\mathrm{O} 141: \mathrm{K} 85,88 \mathrm{ab}$ strains. Both the $\mathrm{O} 8: \mathrm{K} 87$ and $\mathrm{O} 8: \mathrm{K} 87,88 \mathrm{ab}$ strains were strong producers of the LT and ST type of enterotoxin (Smith and Gyles, 1970), and their antisera were known to be able to neutralise the dilating effect of the LT enterotoxin of the $0141: \mathrm{K} 85 \mathrm{ab}, 88 \mathrm{ab}$ strain in the ligated pig intestine.

\section{Effect of antisera against E. coli O141:K85ab,88ab and O8: K87,88ab on mixed infections with these organisms}

Fourteen piglets from two litters were given either O141:K85ab,88ab or $\mathrm{O} 8: \mathrm{K} 87,88 \mathrm{ab}$ antiserum subcutaneously or orally and then infected orally with $10^{7}$ viable organisms of both these strains and $10^{9}$ viable organisms of the nonpathogenic 09:K36:H19 strain. The eight piglets given one or other of these two antisera orally did not develop diarrhoea until approximately $28 \mathrm{hr}$ after infection. Those given antisera subcutaneously developed diarrhoea 13-18 hr after infection. In any particular piglet, the dominant $E$. coli found in the different regions of its small intestine was usually the one that had not been used for preparing the antiserum the piglet had been given. The results of examining four of the piglets are given in table IV. 
Effect of antisera prepared against E. coli $\mathrm{K} 12 \mathrm{~F}^{-} \mathrm{Ent} \mathrm{t}^{+}$on the diarrhoea-producing effect of E. coli O141:K85ab,88ab

The results of giving orally to piglets antisera prepared against live $E$. coli

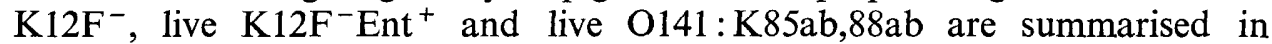
table V. The $\mathrm{K} 12 \mathrm{~F}^{-} \mathrm{Ent}^{+}$strain was the $\mathrm{K}^{+} 2 \mathrm{~F}^{-}$strain to which had been transmitted the Ent plasmid from the O8:K87,88ab strain used in the previous experiments. There was little difference between the five piglets given $\mathrm{K}_{12} \mathrm{~F}^{-}$ antiserum and the four given the $\mathrm{K}_{12} \mathrm{~F}^{-} \mathrm{Ent}^{+}$antiserum in regard to the time interval between infection and the onset of diarrhoea. Both the piglets given $\mathrm{O} 141$ : K85ab,88ab antiserum and for which the time interval recorded in table $\mathrm{V}$ was $>21 \mathrm{hr}$ showed no abnormality when killed at $21 \mathrm{hr}$; only very low concentrations of $\mathrm{O} 141: \mathrm{K} 85 \mathrm{ab}, 88 \mathrm{ab}$ organisms were found in their small intestines. Very high concentrations were found in the small intestines of the other ten piglets which were killed as soon as the onset of diarrhoea was noted.

\section{Discussion}

The results, particularly those on the piglets killed at different times after infection, indicate that antiserum prepared against the enteropathogenic porcine strain of Escherichia coli 0141 : K85ab,88ab markedly inhibits the multiplication of organisms of this strain in the anterior small intestine of piglets to which it had been administered. This antibacterial effect appears to be largely responsible for delaying or preventing the onset of diarrhoea. Had the anti-enterotoxic antibody present in the antiserum been more important in this respect one would have expected to find some piglets with high concentrations of O141: K85ab, $88 \mathrm{ab}$ organisms in the anterior small intestine without diarrhoea. This was not the case. Furthermore, antisera against the E. coli K12Ent ${ }^{+}$and O8:K87 strains had little effect in delaying the onset of diarrhoea caused by the O141:K85ab,88ab strain; these antisera in ligated intestine preparations neutralised the dilating effect of the LT, but not the ST, enterotoxin of O141 : K85ab,88ab (Smith and Gyles, 1970).

The observation that antibacterial activity was also present in antisera prepared against heat-killed and methanol-killed $0141:$ K85ab,88ab organisms has practical significance. So has the observation that antisera prepared against enteropathogenic strains of $E$. coli of antigenic structure different from the 0141 : K85ab,88ab strain had no obvious protective effect against infection with this strain. These findings are in agreement with those obtained by Smith and Gyles in their ligated intestine studies. In the present work, however, a much greater protective effect was obtained against O141:K85ab,88ab infection with antisera prepared from the $08: \mathrm{K} 87,88 \mathrm{ab}$ strain, a protective effect probably attributable to the $\mathrm{K} 88$ antigen common to both of these strains. Since it appears that this antigen permits organisms to adhere to the intestinal epithelium (Smith and Linggood, 1971a), the difference in the degree of protective effect was not unexpected. Whereas adhesion would be of paramount importance in permitting organisms to proliferate in the small intestine of intact piglets, it would probably play no part in permitting proliferation in the ligated 
intestinal segments used by Smith and Gyles. The results of mixed infections with $\mathrm{O} 141: \mathrm{K} 85 \mathrm{ab}, 88 \mathrm{ab}$ and $\mathrm{O} 8: \mathrm{K} 87,88 \mathrm{ab}$ organisms in piglets, however, indicate that antigens other than K88 also play a part in immunity against infections caused by these organisms. The experiments, also indicate that antisera are more effective when administered orally than subcutaneously.

The apparent discrepancy between the results of the present study and those of Kohler (1967) and Miniats et al. (1970) who, although also able to prevent experimental $E$. coli diarrhoea by the oral administration of antiserum, did not observe a marked reduction in the concentration of infecting organisms in the small intestine of protected piglets, may be due to the different techniques employed. I used conventionally born piglets and gave them an infecting dose in which the enteropathogenic organisms were greatly outnumbered by nonpathogenic $E$. coli and lactobacilli in order to simulate the situation that occurs under natural conditions. As a consequence, the enteropathogenic organisms formed only a small proportion of the total bacterial population of the stomach contents of protected and unprotected piglets. In the unprotected piglets, therefore, the concentration of the enteropathogenic organisms found in the small intestine would largely be a reflection of the numbers that had adhered to the intestinal epithelium and subsequently proliferated. In the protected piglets they would also reflect the antibacterial activity of the antiserum, probably at the epithelial surface. Kohler, and Miniats et al., used gnotobiotic piglets monocontaminated with enteropathogenic $E$. coli organisms. In the absence of bacterial competitors, these organisms would colonise the stomach contents in high concentrations and flood through into the small intestine. The high concentrations consequently found in the contents of this organ might well mask the antibacterial activity the antiserum was having at the epithelial surface. On the other hand, it is appreciated that their results using gnotobiotic piglets might indeed be an expression of antitoxic activity not obviously apparent in the kind of piglets used in the present studies.

\section{SUMMARY}

Piglets immediately after normal birth were removed from their mothers and given Escherichia coli antisera by mouth and then infected, also by mouth, with an enteropathogenic strain of E. coli $(\mathrm{O} 141: \mathrm{K} 85 \mathrm{ab}, 88 \mathrm{ab})$ mixed with larger numbers of a non-pathogenic $E$. coli strain and lactobacilli.

When antisera prepared against live, heat-killed or methanol-killed organisms of the O141:K85ab,88ab strain were used, the onset of diarrhoea was delayed or prevented. Antisera prepared against porcine enteropathogenic strains not possessing any of the $\mathrm{O}$ or $\mathrm{K}$ antigens of $\mathrm{O} 141: \mathrm{K} 85 \mathrm{ab}, 88 \mathrm{ab}$ had little effect. So did antiserum against $E$. coli $\mathrm{K} 12$ to which the plasmid responsible for porcine enterotoxin production (Ent) had been transmitted. Antiserum prepared against an enteropathogenic strain $\mathrm{O} 8: \mathrm{K} 87,88 \mathrm{ab}$ had a definite controlling effect, the effect apparently being due to the K88ab antigen common to this strain and the infecting O141:K85ab,88ab strain.

Antisera administered subcutaneously also had a controlling effect on 
experimental $E$. coli diarrhoea, but their effect was markedly less than that of the same sera given orally.

Only low concentrations of enteropathogenic E. coli organisms were found in the contents of the small intestine of piglets in which the diarrhoea was controlled by antiserum, indicating that antibacterial antibody was important in this respect.

I am grateful to Miss Carole Smith and Miss Marion White for their capable technical help. My thanks are also due to Mr L. A. Abbott, Dr R. F. Gordon, Mrs Anne Millington and $\mathrm{Mr} \mathrm{W.} \mathrm{J.} \mathrm{Sojka} \mathrm{for} \mathrm{assistance} \mathrm{in} \mathrm{a} \mathrm{variety} \mathrm{of} \mathrm{ways.}$

\section{REFERENCES}

KOHLER, E. M. 1967. Studies of Escherichia coli in gnotobiotic pigs. V. Evaluation of the effects of oral and parenteral administration of immune serum. Canad.J. Comp. Med., 31, 283.

Kohler, E. M., AND Bohl, E. H. 1966. Studies of Escherichia coli in gnotobiotic pigs. III. Evaluation of orally administered specific antisera. Canad. J. Comp. Med., 30, 233.

Miniats, O. P., Mitchell, L., AND Barnum, D. A. 1970. Response of gnotobiotic pigs to Escherichia coli. Canad. J. Comp. Med., 34, 269.

Rogosa, M., Mitchell, Joyce A., And Wiseman, R. F. 1951. A selective medium for the isolation and enumeration of oral and fecal lactobacilli. J. Bact., 62, 132.

SMrth, H. W., AND GyLES, C. L. 1970. The relationship between two apparently different enterotoxins produced by enteropathogenic strains of Escherichia coli of porcine origin. J. Med. Microbiol., 3, 387.

Smith, H. W., AND LingGood, Margaret A. 1971a. Observations on the pathogenic properties of the K88, Hly and Ent plasmids of Escherichia coli with particular reference to porcine diarrhoea. J. Med. Microbiol., 4, 467.

SMith, H. W., AND LINGGOOD, MARgaret A. 1971 b. The effect of antisera in protecting pigs against experimental Escherichia coli diarrhoea and oedema disease. J. Med. Microbiol., 4, 487. 